\title{
Effect of Corn Silage from an Herbicide-Tolerant Genetically Modified Variety on Milk Production and Absence of Transgenic DNA in Milk
}

\author{
R. H. Phipps, ${ }^{1}$ A. K. Jones, ${ }^{1}$ A. P. Tingey, ${ }^{2}$ and S. Abeyasekera ${ }^{3}$ \\ ${ }^{1}$ Centre for Dairy Research, School of Agriculture, Policy and Development, \\ The University of Reading, RG6 6AR, UK \\ ${ }^{2}$ Reading Scientific Services Ltd, Lord Zuckerman Research Centre, \\ Whiteknights Campus, Pepper Lane, Reading RG6 6LA, UK \\ ${ }^{3}$ Statistical Services Centre, School of Applied Statistics, \\ The University of Reading, Reading RG6 6FN
}

\begin{abstract}
Data from 60 multiparous Holstein cows were used in a 12-wk continuous design feeding trial. Cows were allocated to 1 of 4 experimental treatments (T1 to T4). In $\mathrm{T} 1$ and $\mathrm{T} 2$, the total mixed ration (TMR) contained either corn silage from the genetically modified (GM) variety Chardon Liberty Link, which is tolerant to the herbicide glufosinate ammonium, or its near isogenic nonGM counterpart, whereas the TMR used in T3 and T4 contained corn silage from the commercially available nonGM varieties Fabius and Antares, respectively. The objectives of the study were to determine if the inserted gene produced a marked effect on chemical composition, nutritive value, feed intake, and milk production, and to determine if transgenic DNA and the protein expressed by the inserted gene could be detected in bovine milk. The nutritive value, fermentation characteristics, mineral content, and amino acid composition of all 4 silages were similar. There were no significant treatment effects on milk yield, milk composition, and yield of milk constituents, and the dry matter (DM) intake of the GM variety was not significantly different from the 2 commercial varieties. However, although the DM intake noted for the nonGM near-isogenic variety was similar to the commercial varieties, it was significantly lower when compared with the GM variety. Polymerase chain reaction analyses of milk samples collected at wk 1, 6 , and 12 of the study showed that none of the 90 milk samples tested positive, above a detection limit of $2.5 \mathrm{ng}$ of total genomic $\mathrm{DNA} / \mathrm{mL}$ of milk, for either tDNA (event T25) or the single-copy endogenous Zea mays gene, alcohol dehydrogenase. Using ELISA assays, the protein expressed by the T25 gene was not detected in milk.
\end{abstract}

Received November 9, 2004.

Accepted April 22, 2005.

Corresponding author: R. H. Phipps; e-mail: r.h.Phipps@ reading.ac.uk.
(Key words: genetically modified corn silage, nutritive value, milk production, DNA detection)

Abbreviation key: GM = genetically modified, $\mathbf{L L}=$ Liberty Link, LOD = limit of detection, $\mathbf{M E}=$ metabolizable energy, PAT = phosphinothricin acetyltransferase, protein encoded by pat gene, tDNA = transgenic DNA.

\section{INTRODUCTION}

The total area of genetically modified (GM) crops grown globally is increasing, and had reached 80 million ha in 2004 (James, 2004). Soybeans, corn, canola, and cotton modified for agronomic input traits such as herbicide tolerance and insect protection are all used in livestock rations. They are present either as a whole crop such as corn silage, or as specific crop components or coproducts such as corn grain or oilseed meals. A number of recent studies (Phipps et al., 2002, 2003; Calsamiglia et al., 2003; Grant et al., 2003; Ipharraguerre et al., 2003) and the review carried out by the Organization for Economic Cooperation and Development (OECD, 2003) showed that the inclusion of GM feed ingredients in dairy cow diets did not affect feed intake or milk production. Moreover, to date, neither transgenic DNA (tDNA) nor the expressed protein from the inserted gene has been detected in milk.

The Royal Society recently published the results of a 4-yr farm scale evaluation of spring-sown GM crops grown in the United Kingdom (Royal Society, 2003). The GM corn variety used in the study was Chardon Liberty Link (LL), which was modified to be tolerant to the herbicide glufosinate ammonium (event T25) and it would have been grown for silage if grown in northern Europe. In the current study, Chardon LL, its near isogenic nonGM counterpart, and 2 commercial forage corn hybrids were grown and fed as part of a TMR to lactating dairy cows. The aim was to determine if the introduced GM trait significantly affected milk production and if tDNA and the protein expressed by the inserted gene could be detected in milk derived from cows receiving the TMR containing GM corn silage. 


\section{MATERIALS AND METHODS}

\section{Crop Production and Harvesting}

The corn variety Chardon LL (Bayer CropScience, Cambridge, UK) is derived from the transformation event T25, which contains the pat gene encoding for an enzyme (phosphinothricin $\mathrm{N}$-acetyl transferase) that inactivates the herbicidal activity of glufosinate ammonium thus bestowing herbicide tolerance to the plant. Chardon LL, its near-isogenic nonGM counterpart, and 2 commercial forage corn hybrids, var. Fabius (Advanta Seeds, Sleaford, UK) and Antares (Syngenta Seeds, Cambridge, UK) were grown at the University of Reading. Varieties Fabius and Antares are in Maturity Classes 8 and 6 (Maize Growers Association, 2002) and were chosen because they were widely grown and considered to be representative of what many farmers would use and were of a similar maturity class to Chardon LL. With the exception of weed control, all 4 varieties were grown under similar general management conditions being planted in late April at a plant density of 109,000 seeds/ha. Weed control for the nonGM varieties was achieved using 2 split applications of Atrazine (3.0 L/ha) and Bromotril (1.6 L/ha), whereas weed control for Chardon LL was achieved with one application of glufosinate ammonium (3.0 L/ha). To comply with government regulations, there was a separation distance greater than $80 \mathrm{~m}$ between Chardon LL and other forage corn varieties used in the study.

All crops were harvested and ensiled in clamps in late October when whole-crop DM content was estimated to be approximately $350 \mathrm{~g} / \mathrm{kg}$.

\section{Cows, Experimental Design, and Diets}

The work was conducted under the authority of the UK Animals (Scientific Procedures) Act 1986 (Home Office, 1986) and under the control of staff holding appropriate licenses under the Act. All cows were housed in cubicle yards with sawdust for bedding and with ad libitum access to potable water.

Sixty-four multiparous Holstein cows that had completed $75 \pm 8.4$ DIM, with an initial live weight of 656 $\pm 53 \mathrm{~kg}$ and milk yield of $36.1 \pm 4.4 \mathrm{~kg} / \mathrm{d}$ were used in a 12-wk continuous design feeding trial. From calving, these cows had been group-fed a TMR containing forage and concentrate in a 52:48 DM ratio. Corn and grass silage formed 390 and $130 \mathrm{~g} / \mathrm{kg}$ of total dietary DM, and cracked wheat, rapeseed meal, distiller's wheat, and minerals contributed $180,145,140$, and $15 \mathrm{~g} / \mathrm{kg}$ of total dietary DM, respectively. These ration ingredients produced a mean value for $\mathrm{DM}, \mathrm{CP}, \mathrm{NDF}$, starch, and metabolizable energy (ME) of $463 \mathrm{~g} / \mathrm{kg}$ of fresh weight, $175,347,244 \mathrm{~g} / \mathrm{kg}$ of DM, and $12.0 \mathrm{MJ} / \mathrm{kg}$ of DM, respec- tively. The diet composition was chosen to provide continuity with earlier studies conducted at Reading (Phipps et al., 2003).

On a given date, the 64 cows were allocated to 4 treatments (T1, T2, T3, T4) based on milk yield, parity, calving date, and live weight. A predesigned blocking matrix was used to determine the treatment to which animals were assigned. For animals to be accepted within a block they had to have calved within $28 \mathrm{~d}$ of each other, have milk yields and live weights within 3 $\mathrm{kg} / \mathrm{d}$ and $50 \mathrm{~kg}$ (as measured in the 2 previous weeks), and should be of the same parity. Sixteen blocks were formed. On treatment allocation, cows were then moved to yards with individual feeding. The next $2 \mathrm{wk}$ were used for the cows to acclimate to individual feeding, and the third week was used as a covariate period. During this 3-wk period, all cows were offered the same TMR, which was the same as that offered from calving, as described above.

The 4 experimental TMR diets were introduced at the start of the following week. The diets contained the same proportion of ingredients as used in the covariate period and only differed in the origin of the corn silage. The TMR offered to T1, T2, T3, and T4 contained corn silage derived from the GM variety (Chardon LL), its near-isogenic nonGM corn counterpart, and the commercially available nonGM corn varieties Fabius and Antares, respectively.

\section{Sampling Procedures and Measurements}

Feed analyses. At ensiling, samples (500 g fresh wt) of fresh chopped whole crop corn were obtained from each trailer delivering Chardon LL and the nonGM near-isogenic counterpart to the bunker for ensiling. The material collected for each variety was bulked and thoroughly mixed and 6 subsamples were taken and immediately frozen $\left(-20^{\circ} \mathrm{C}\right)$ for subsequent analysis to confirm the provenance of the material to be used in the feeding study.

During the 12-wk experimental feeding period, silage samples $(250 \mathrm{~g} / \mathrm{sample})$ were taken weekly from the top, middle, and bottom third of the clamp face of the grass silage and the 4 corn silages and then frozen. At the end of the study, the grass and corn silage samples were bulked on a 4 -wk basis and then subsampled to provide a single sample for each 4 -wk period. This produced 3 samples for each forage component. Silage samples were analyzed for a full range of nutritional and fermentation characteristics, minerals, and amino acids (Natural Resources Managements, Bracknell, UK). Oven-dried $\left(60^{\circ} \mathrm{C}\right.$ until static weight) silage samples were analyzed for DM, CP, NDF, starch, and watersoluble carbohydrates using near infrared spectroscopy 
(Foss 5000 NIR Systems, York, UK). The ME content for grass silage, corn silages, and concentrate supplement were estimated (Givens et al., 1995; Offer et al., 1996). Gas chromatography (Agilent 6890 Series GC system) and inductively coupled plasma optical emission spectroscopy (Perkin Elmer Optima 3000 Series) and a Bichrom 20 Amino Acid analyzer were used to determine silage fermentation characteristics, and the mineral and amino acid composition of fresh silage samples, respectively.

Samples of cracked wheat, rapeseed meal, and distiller's wheat were taken weekly, bulked on a 4-wk basis, and subsequently analyzed for DM, CP, NDF, starch, water-soluble carbohydrates, oil, and ME content. Feed samples were analyzed by wet chemistry methods [Natural Resource Management, Bracknell, UK; Ministry of Agriculture, Fisheries, and Food (1993)].

The results of the analyses obtained for the silages and the concentrate supplements were used to calculate the nutritional value of the TMR offered during the experimental period.

Feed intake. Fresh TMR were prepared daily in an RMH mixer feeder wagon (Lachish Industries, Sderot, Israel) and offered on an individual cow basis at 0900 $\mathrm{h}$ through an electronic feeding gate system (American Calan, Northwood, NH). To ensure cows had ad libitum access to the TMR, the amount to be offered to individual cows was assessed on a daily basis with the aim of producing a 5 and $10 \%$ refusal. Due to labor constraints, refusals were removed $(0700 \mathrm{~h})$ and measured 3 times a week (Monday, Wednesday, and Friday). Individual daily feed intakes were calculated on a weekly basis by subtracting the refusals measured during that week from the total fresh TMR offered in that week. The DM content (determined by drying at $60^{\circ} \mathrm{C}$ until static weight) of the TMR for that week was then applied to both the offered and refused feed to estimate the individual daily DM intake on a weekly basis. In these calculations, it was assumed that the DM content of the offered and refused TMR was the same.

Live weight and BCS. Cows were weighed and body condition was scored (Mulvanny, 1977) in the week before treatment allocation and then weekly during the experimental feeding period. All weights were recorded on Wednesday morning before feed allocation on that day.

Milk yield and composition. Cows were milked twice daily at 0500 and $1500 \mathrm{~h}$ through a Fullwood herringbone parlor with automatic cow identification, automatic cluster removal, and Fullflow inline milk meters (Fullwood Co., Ellesmere Port, UK) to record and sample milk. Individual milk yields were recorded automatically for all cows at each milking. In the week before the start of the experimental period and in each subsequent week, 25-mL milk samples from 2 consecutive milkings (Tuesday p.m. and Wednesday a.m.) were analyzed for fat, protein (total nitrogen $\times 6.38$ ), and lactose concentration using an infrared milk analyzer (Foss Electric). These data were combined with corresponding milk yields to produce mean weekly milk composition data. The yields of milk constituents were calculated using average weekly a.m. and p.m. milk yield and milk composition data.

Two additional milk samples $(2 \times 30 \mathrm{~mL})$ were collected from all cows on the Thursday p.m. and Friday a.m. in the week before the start of the experimental period and then in experimental wk 1, 6, and 12. These samples were collected in sterile conical centrifuge tubes (British Drug Houses, London, UK), frozen, and subsequently used for the tDNA and novel protein analyses. Polymerase chain reaction analysis for detection of the specific GM DNA and ELISA assays for the detection of the novel protein [phosphinothricin acetyltransferase (PAT) protein] were carried out on these milk samples by Reading Scientific Services Ltd. (The Lord Zuckerman Research Centre, Reading University, UK).

\section{PCR and ELISA}

DNA extraction and purification. Total DNA was isolated from milk samples $(4 \mathrm{~mL})$ by precipitation with the addition of sodium acetate to a final concentration of $0.3 \mathrm{M}$ and 2 volumes of absolute ethanol. The precipitate was collected by centrifugation $(1100 \times g, 5 \mathrm{~min})$ and was then weighed and treated as for silage samples (see below). Silage samples were finely ground using high-performance blender systems and then analyzed as separate duplicate subsamples. To establish whether the method of DNA extraction had any effect on results, DNA was extracted from the samples using 3 methods. The results were unaffected by DNA extraction methodology. Using an adapted cetyl trimethyl ammonium bromide method (Doyle and Doyle, 1987), DNA was extracted from $300 \mathrm{mg}$ of ground frozen silage. The Wizard Miniprep DNA Purification System (Promega, UK) was also used to extract DNA from 350-mg silage samples using a protocol originally developed to extract DNA from fresh leaf tissue (Bayer CropScience NV, Belgium; adapted from Zimmerman et al., 1998). Finally, DNA was extracted from precipitated milk and ground silage using a protocol developed by Reading Scientific Services Ltd. (unpublished data) using detergent buffer, proteinase K, Rnase A, and Plant DNeasy DNA extraction columns (Qiagen Ltd., Crawley, UK). All extracted DNA was stored frozen at $-20^{\circ} \mathrm{C}$ until used.

The extracted DNA from all samples was resuspended in $200 \mu \mathrm{L}$ of molecular biology-grade water. The yield and purity of the extracted DNA (1:20 dilution) 
was determined following measurement of UV absorption at $\mathrm{A}_{260}$ and $\mathrm{A}_{280}$. During each extraction procedure, an extraction control (duplicate) was carried out using the same buffers and reagents. The extraction controls were included in each PCR assay as controls for contamination during DNA extraction.

Primer selection. Primers were supplied and designed by Bayer CropScience and were used in a duplex PCR reaction to give 2 amplicons specific to a singlecopy endogenous corn gene (Zea mays alcohol dehydrogenase, accession number M32984 (Genbank)) and the pat gene. Amplified fragments of $513 \mathrm{bp}$ (endogenous gene) were produced by the COR15/COR 16 primer pair, and of $320 \mathrm{bp}$ (pat gene) were produced by the COR19/ COR20 primers. Sequences of the primers were: COR 155'-AGCGTCAAGGATCATTGGTGTC-3';COR165'GGCCAAGTTCAGCATAAGCTGT-3',COR195'-AGG AGCTGGCAACTCAAAATCC-3', and COR205'-GTGT TGTGGCTGGTATTGCTTACGC-3'. The GM (T25) corn would be expected to produce 2 PCR products from this duplex reaction; all other corn types should only yield a PCR product from the endogenous gene reaction.

PCR methodology. For milk and silage preparations, $5 \mu \mathrm{L}$ of the isolated DNA was added per reaction and PCR was carried out in a final volume of $25 \mu \mathrm{L}$. The reaction mix contained $200 \mu M$ dNTP mix (Roche Diagnostics GmbH, Germany), $200 \mathrm{n} M$ of each the COR19 and COR20 primers, $100 \mathrm{n} M$ of each of the COR15 and COR16 primers, $1.5 \mathrm{mM}$ magnesium chloride, and $0.5 \mathrm{U}$ of Platinum Taq DNA polymerase (Invitrogen, UK). The PCR was carried out using a GeneAmp PCR System 9700 (Applied Biosystems, Warrington, UK) and the following temperature profile: initial denaturation at $95^{\circ} \mathrm{C}$ for $4 \mathrm{~min}$, followed by 5 cycles of $95^{\circ} \mathrm{C}$ for $1 \mathrm{~min}, 57^{\circ} \mathrm{C}$ for $1 \mathrm{~min}, 72^{\circ} \mathrm{C}$ for $2 \mathrm{~min}$, followed by a further 35 cycles of $92^{\circ} \mathrm{C}$ for $30 \mathrm{~s}, 57^{\circ} \mathrm{C}$ for $30 \mathrm{~s}, 72^{\circ} \mathrm{C}$ for $1 \mathrm{~min}$. The reactions were completed with a hold at $72^{\circ} \mathrm{C}$ for $5 \mathrm{~min}$ and final dwell at $4^{\circ} \mathrm{C}$. When assembling each PCR plate, a positive control using DNA from the corn variety T25, a negative control ( $5 \mu \mathrm{L}$ of water), and an extraction control for the sample DNA to be amplified were routinely set up.

The limit of detection (LOD) of each amplicon in each sample type was determined using LOD assays. A titration of T25 corn DNA was spiked into duplicate milk samples, and a PCR analysis was carried out for each amplicon; the lowest amount of target DNA detectable in duplicate milk samples was called the LOD. This LOD test was repeated on separate duplicate milk samples on 3 occasions. The LOD for total genomic DNA was established as $2.5 \mathrm{ng}$ of $\mathrm{DNA} / \mathrm{mL}$ of milk.

Agarose gel electrophoresis. Twenty microliters of PCR product was mixed with $4 \mu \mathrm{L}$ of loading dye [50\% $\mathrm{vol} / \mathrm{vol}$ glycerol, $60 \mathrm{~m} M$ Tris $\mathrm{HCl}$, pH 7.5, $120 \mathrm{~m} M \mathrm{NaCl}$,
$0.6 \mathrm{~m} M$ EDTA, $3 \mathrm{mg} / \mathrm{mL}$ bromophenol blue (BioRad Laboratories, UK)] and separated using a 1.5\% (wt/vol) agarose gel, containing $100 \mu \mathrm{g} / \mathrm{mL}$ ethidium bromide. Electrophoresis was carried out at $200 \mathrm{~V}$ for 1.5 to $2 \mathrm{~h}$, and the DNA was visualized under UV light.

Transgenic protein analyses. Milk samples were tested for the presence of PAT (encoded by the pat gene in T25 corn) using a commercially available test kit purchased from Steffens Biotechnische Analysen (D79285 Ebringen, Germany). The kit was validated for use with milk by spiking the positive control protein into blank milk samples. The milk was tested by adding it directly to the kit as samples run alongside the supplied standards. Spiking experiments were carried out to determine the LOD of the PAT protein in milk; the LOD was $3 \mathrm{ng} / \mathrm{mL}$.

\section{Statistical Analyses}

The results of the feeding study were analyzed using a GLM procedure for a randomized block design using the statistical package Genstat 7 (2003; Lawes Agricultural Trust, Rothamsted Experimental Station, UK). Student's $t$-tests were used to carry out specific treatment comparisons. Four cows were removed during the study due to mastitis, lameness, and inappetence. Data from the remaining 60 cows were used in the analysis. Mean values for milk production and DM intake were adjusted for blocks and the corresponding values in the pretreatment period, whereas live weight gain was adjusted for blocks and initial live weight in the covariate period.

The results of the PCR analyses were expressed as positive, negative, or inconclusive. In every PCR run, the results of the PCR plate were only accepted when the positive control was positive and the negative control and extraction controls were negative for the specific amplicon. A true positive was only recorded when the correct-sized PCR product was visualized on the ethidium bromide-stained gel for the duplicate PCR. As in a previous published study (Phipps et al., 2003) no further statistical analysis was undertaken.

\section{RESULTS AND DISCUSSION}

\section{Feed Analyses}

The nutritional value, fermentation characteristics, mineral composition, and amino acid concentration of the grass silage used in all treatments and the 4 corn silages used in T1 to T4 are shown in Tables 1 and 2 . The standard error of the mean for the 4 corn silages is shown as an indication of the variation in the 4 corn silages. 
Table 1. Chemical composition and fermentation characteristics of the grass silage and the 4 corn silages included in the TMR used in the feeding study.

\begin{tabular}{|c|c|c|c|c|c|c|}
\hline \multirow[b]{2}{*}{$\begin{array}{l}\text { Composition } \\
(\mathrm{g} / \mathrm{kg} \text { of } \mathrm{DM})^{1}\end{array}$} & \multirow[b]{2}{*}{$\begin{array}{l}\text { Grass } \\
\text { silage }\end{array}$} & \multicolumn{4}{|c|}{ Corn silage } & \multirow[b]{2}{*}{$\begin{array}{l}\mathrm{SEM}^{2} \\
(8 \mathrm{df})\end{array}$} \\
\hline & & $\begin{array}{l}\text { Chardon } \\
\text { Liberty } \\
\text { Link }\end{array}$ & $\begin{array}{l}\text { Near- } \\
\text { isogenic }\end{array}$ & Fabius & Antares & \\
\hline DM (g/kg fresh wt) & 293 & 331 & 366 & 337 & 352 & 7.60 \\
\hline $\mathrm{CP}$ & 104 & 73 & 67 & 75 & 76 & 2.02 \\
\hline $\mathrm{ME}^{3}(\mathrm{MJ} / \mathrm{kg}$ of $\mathrm{DM})$ & 11.6 & 10.9 & 11.4 & 11.2 & 11.2 & 0.355 \\
\hline NDF & 492 & 395 & 362 & 361 & 374 & 16.80 \\
\hline Water-soluble carbohydrates & 35 & 34 & 48 & 34 & 20 & 11 \\
\hline Starch & $<0.1$ & 295 & 338 & 331 & 337 & 9.73 \\
\hline Ash & 64 & 42 & 39 & 36 & 43 & 4.41 \\
\hline pH & 3.8 & 3.8 & 3.8 & 3.7 & 3.7 & 0.06 \\
\hline $\mathrm{NH}_{3}-\mathrm{N}(\mathrm{g} / \mathrm{kg}$ of total $\mathrm{N})$ & 56 & 56 & 68 & 60 & 64 & 2.7 \\
\hline Lactic acid & 167 & 88 & 83 & 87 & 94 & 4.1 \\
\hline Ethanol & 13 & 8.7 & 4.7 & 6.7 & 7.0 & 1.7 \\
\hline Acetic acid 4 & 30 & 21 & 17 & 31 & 18 & 3.0 \\
\hline
\end{tabular}

${ }^{1}$ Unless otherwise stated.

${ }^{2}$ Standard error of the mean for the 4 corn silages.

${ }^{3} \mathrm{ME}=$ Metabolizable energy.

${ }^{4}$ Butyric, propionic, and valeric acid contents were all $<1 \mathrm{~g} / \mathrm{kg}$ of DM.

Table 2. Mineral and amino acid concentration of the grass silage and 4 corn silages included in the TMR used in the feeding study.

\begin{tabular}{|c|c|c|c|c|c|c|}
\hline & \multirow[b]{2}{*}{$\begin{array}{l}\text { Grass } \\
\text { silage }\end{array}$} & \multicolumn{4}{|c|}{ Corn silage } & \multirow[b]{2}{*}{$\begin{array}{l}\mathrm{SEM}^{1} \\
(8 \mathrm{df})\end{array}$} \\
\hline & & $\begin{array}{l}\text { Chardon } \\
\text { Liberty } \\
\text { Link }\end{array}$ & $\begin{array}{l}\text { Near- } \\
\text { isogenic }\end{array}$ & Fabius & Antares & \\
\hline \multicolumn{7}{|c|}{ Mineral value ( $\mathrm{g} / \mathrm{kg}$ of $\mathrm{DM})$} \\
\hline Phosphorous & 3.5 & 2.4 & 2.5 & 2.4 & 2.8 & 0.08 \\
\hline Potassium & 26 & 12 & 12 & 9.5 & 13 & 0.56 \\
\hline Magnesium & 1.5 & 1.3 & 1.3 & 1.4 & 1.4 & 0.05 \\
\hline Calcium & 6.3 & 2.5 & 2.4 & 3.1 & 2.1 & 0.09 \\
\hline Sodium & 1.6 & 0.1 & 0.1 & $<0.1$ & 0.1 & 0.02 \\
\hline Sulfur & 1.5 & 0.97 & 0.93 & 1.1 & 0.40 & 0.15 \\
\hline Manganese $^{2}$ & 144 & 18 & 16 & 16 & 18 & 1.14 \\
\hline Copper $^{2}$ & 6.9 & 5.0 & 5.2 & 5.4 & 3.8 & 0.16 \\
\hline Iron $^{2}$ & 254 & 114 & 96 & 107 & 88 & 12.0 \\
\hline $\mathrm{Zinc}^{2}$ & 23 & 18 & 21 & 16 & 11 & 0.57 \\
\hline \multicolumn{7}{|c|}{ Amino acid composition ( $\mathrm{g} / \mathrm{kg}$ of $\mathrm{DM})$} \\
\hline Aspartic acid & 11.1 & 4.9 & 4.4 & 4.7 & 5.4 & 0.17 \\
\hline Threonine & 4.4 & 2.9 & 2.6 & 2.8 & 3.1 & 0.09 \\
\hline Serine & 4.8 & 3.6 & 3.4 & 3.6 & 4.4 & 0.29 \\
\hline Glutamic acid & 10 & 10 & 9.4 & 12 & 13 & 0.43 \\
\hline Glycine & 5.4 & 3.5 & 3.4 & 3.6 & 3.5 & 0.15 \\
\hline Alanine & 9.7 & 6.2 & 6.1 & 7.1 & 6.9 & 0.27 \\
\hline Valine & 6.5 & 4.0 & 3.8 & 4.2 & 4.4 & 0.12 \\
\hline Isoleucine & 4.7 & 2.3 & 2.3 & 2.7 & 2.9 & 0.08 \\
\hline Leucine & 7.5 & 5.8 & 5.9 & 7.5 & 8.6 & 0.14 \\
\hline Tyrosine & 2.3 & 1.6 & 1.3 & 2.1 & 1.8 & 0.12 \\
\hline Phenylalanine & 4.4 & 2.7 & 2.7 & 3.6 & 4.0 & 0.12 \\
\hline Histidine & 2.1 & 1.8 & 1.9 & 2.3 & 1.9 & 0.09 \\
\hline Arginine & 2.1 & 1.6 & 1.4 & 1.8 & 1.8 & 0.07 \\
\hline Proline & 5.7 & 5.3 & 5.1 & 6.0 & 6.3 & 0.17 \\
\hline Total lysine & 4.3 & 2.2 & 2.1 & 2.1 & 2.2 & 0.10 \\
\hline Cysteine & 0.8 & 1.0 & 1.1 & 1.1 & 1.2 & 0.06 \\
\hline Methionine & 1.5 & 1.0 & 1.1 & 1.0 & 1.2 & 0.06 \\
\hline
\end{tabular}

${ }^{1}$ Standard error of the mean for the 4 corn silages.

${ }^{2} \mathrm{In} \mathrm{mg} / \mathrm{kg}$ of DM. 
Table 3. Chemical composition of the cracked wheat, rapeseed meal, and distillers wheat included in the TMR used in the feeding study.

\begin{tabular}{|c|c|c|c|c|c|c|}
\hline \multirow[b]{2}{*}{$\begin{array}{l}\text { Composition } \\
\text { ( } \mathrm{g} / \mathrm{kg} \text { of DM unless otherwise stated) }\end{array}$} & \multicolumn{2}{|c|}{ Cracked wheat } & \multicolumn{2}{|c|}{ Rapeseed meal } & \multicolumn{2}{|c|}{ Distillers wheat } \\
\hline & Mean & $\begin{array}{l}\mathrm{SEM}^{1} \\
(3 \mathrm{df})\end{array}$ & Mean & $\begin{array}{l}\text { SEM } \\
(3 \mathrm{df})\end{array}$ & Mean & $\begin{array}{l}\text { SEM } \\
(3 \mathrm{df})\end{array}$ \\
\hline DM (g/kg of fresh wt) & 864 & 0.882 & 884 & 0.000 & 906 & 0.00 \\
\hline $\mathrm{CP}$ & 145 & 1.202 & 384 & 0.000 & 331 & 0.577 \\
\hline Metabolizable energy (MJ/kg of DM) & 13.6 & 0.000 & 12.2 & 0.033 & 13.5 & 0.115 \\
\hline NDF & 97 & 1.90 & 334 & 1.20 & 366 & 7.97 \\
\hline Water-soluble carbohydrates & 31 & 0.78 & 98 & 0.31 & 49 & 1.21 \\
\hline Starch & 690 & 7.84 & 58 & 0.67 & 22 & 2.00 \\
\hline Oil & 25 & 0.46 & 55 & 0.58 & 69 & 0.64 \\
\hline Ash & 20 & 0.60 & 82 & 0.46 & 49 & 0.44 \\
\hline
\end{tabular}

${ }^{1}$ Standard error of the mean for the feed ingredients.

The grass silage had a high energy concentration of $11.6 \mathrm{MJ} / \mathrm{kg}$ of DM and was well fermented with low $\mathrm{pH}$ and ammonia nitrogen values. Although the DM content of Chardon LL silage was somewhat lower than its near-isogenic counterpart (331 vs. $366 \mathrm{~g} / \mathrm{kg}$ ), it was in the same range as the 2 commercial varieties, Fabius $(337 \mathrm{~g} / \mathrm{kg})$ and Antares $(352 \mathrm{~g} / \mathrm{kg})$. The difference in crop maturity is attributed to the fact that the GM variety was grown in a different field than the nonGM varieties because of legal requirements; the variation in maturity was attributed to variation in field microclimates. All corn silages were well fermented and had similar fermentation characteristics. The results in Tables 1 and 2 indicate that, with few exceptions, there were only minor differences in silage composition when comparing Chardon LL, its near-isogenic nonGM counterpart, and the commercially available hybrids, Fabius and Antares. The values recorded in the current study are within the expected compositional range (OECD, 2002; International Life Sciences Institute, 2004).

The nutritive values of the concentrate ingredients (Table 3) added to the forages to form the TMR were also in the expected nutritional range for these supplements (Ministry of Agriculture, Fisheries, and Food, 1993). Based on the inclusion rates and compositional analyses of the forages and concentrate ingredients incorporated into the TMR, the nutritional composition of the 4 experimental rations fed in the lactation study were estimated and found to be similar (Table 4). The DM, $\mathrm{CP}$, starch, NDF, and predicted ME concentrations for $\mathrm{T} 1, \mathrm{~T} 2, \mathrm{~T} 3$, and $\mathrm{T} 4$ were $434,457,438$, and $448 \mathrm{~g}$ of $\mathrm{DM} / \mathrm{kg}$ fresh weight; $170,168,171$, and $171 \mathrm{~g}$ of CP/kg of DM; 251, 268, 265, and $267 \mathrm{~g}$ of $\mathrm{starch} / \mathrm{kg}$ of DM; $335,322,322$, and $327 \mathrm{~g}$ of NDF/ $/ \mathrm{kg}$ of DM, and 11.9 , 12.0, 12.0, and $12.0 \mathrm{MJ} / \mathrm{kg}$ of DM, respectively.

\section{Lactation Study}

During the study period, one cow was removed from each treatment group. One animal each was removed from groups T1 and T2 due to mastitis; one animal was removed from T3 due to inappetence; and one animal from $\mathrm{T} 4$ because of lameness. The authors feel that the exclusion of these 4 animals did not influence the overall results of the study.

The study showed no significant differences between the 4 dietary treatments for milk yield, milk composition, and yield of milk constituents (Table 5). In particular, there were no significant treatment effects when comparing Chardon LL (T1) with the near-isogenic nonGM variety (T2). In addition, there was no significant difference in DM intake when comparing the GM variety Chardon LL and the 2 commercial varieties, Fabius and Antares. However, although the DM intake for the near-isogenic nonGM counterpart was similar to the commercial varieties, it was significantly lower $(P=0.013)$ when compared with the GM variety. This lower intake may have been due to the higher DM content of nonGM near-isogenic silage, which approached the level at which a reduction in DM intake has previously been recorded in the UK (Phipps et al., 2000). During the experimental feeding period, there was no significant difference in live-weight gain when comparing the GM variety Chardon LL and the 2 commercial varieties. However, the live-weight gain recorded for the cows receiving the nonGM near-isogenic counterpart was significantly higher $(P<0.001)$ compared with the GM variety. This difference is difficult to explain, especially as there was no significant difference between BCS recorded for the 4 treatment groups during the experimental period. The lack of significant treatment effects in terms of milk yield and composition was expected, as the chemical analyses of the 4 ensiled corn varieties used in the current study were similar. In reviewing this area of study, Flachowsky and Aulrich (2001) and Clark and Ipharraguerre (2001) noted that once a similar compositional value is established, then animal performance is also similar. The results from the current study would support this general view, but 
Table 4. The nutritional value of the TMR used in the experimental feeding period, calculated from the chemical composition of the individual ingredients used.

\begin{tabular}{|c|c|c|c|c|c|}
\hline \multirow{4}{*}{$\begin{array}{l}\text { Composition } \\
\text { ( } \mathrm{g} / \mathrm{kg} \text { of DM unless otherwise stated) }\end{array}$} & \multicolumn{4}{|c|}{ TMR treatments } & \multirow{4}{*}{$\begin{array}{l}\text { SEM }^{1} \\
(8 \mathrm{df})\end{array}$} \\
\hline & \multirow{3}{*}{ 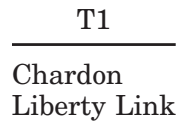 } & \multirow{3}{*}{$\frac{\mathrm{T} 2}{\text { Near-isogenic }}$} & \multirow{3}{*}{$\frac{\mathrm{T} 3}{\text { Fabius }}$} & \multirow{3}{*}{$\frac{\mathrm{T} 4}{\text { Antares }}$} & \\
\hline & & & & & \\
\hline & & & & & \\
\hline $\mathrm{DM}$ (g/kg of fresh wt) & 434 & 457 & 438 & 448 & 5.17 \\
\hline $\mathrm{CP}$ & 170 & 168 & 171 & 171 & 0.807 \\
\hline NDF & 335 & 322 & 322 & 327 & 6.56 \\
\hline Starch & 251 & 268 & 265 & 267 & 7.70 \\
\hline Water-soluble carbohydrates & 44 & 50 & 45 & 39 & 4.3 \\
\hline Ash & 49 & 47 & 46 & 49 & 1.8 \\
\hline Metabolizable energy (MJ/kg of DM) & 11.9 & 12.0 & 12.0 & 12.0 & 0.139 \\
\hline Phosphorous & 5.5 & 5.5 & 5.5 & 5.7 & 0.03 \\
\hline Potassium & 13.1 & 13.0 & 12.0 & 13.3 & 0.209 \\
\hline Magnesium & 2.9 & 2.9 & 2.9 & 2.9 & 0.02 \\
\hline Calcium & 7.2 & 7.2 & 7.5 & 7.1 & 0.04 \\
\hline Sodium & 1.4 & 1.4 & 1.4 & 1.4 & 0.01 \\
\hline
\end{tabular}

${ }^{1}$ Standard error of the mean for the 4 TMR treatments.

there is likely to be a continuing requirement for in vivo studies as part of the safety assessment.

\section{Detection of Transgenic DNA and Protein}

GM constructs and near-isogenic counterpart. The results of the PCR analyses of 6 Chardon LL fresh corn samples taken at the time of ensiling confirmed the presence of the T25 construct, whereas the 6 samples taken from the nonGM near-isogenic counterpart were all negative. Although these results confirmed the correct provenance of the ensiled material used in the feeding study, positive results for the pat amplicon for the GM silage (T25) used during the feeding study were not obtained consistently, but all PCR analyses of silage from the nonGM isogenic counterpart were negative. These results confirm the earlier findings by both Hupfer et al. (1999) and Aulrich et al. (2004), who noted the lack of consistency in positive results recorded for GM silage and suggested that this was due to the ensiling process causing marked DNA degradation. Moreover, Hupfer et al. (1999) noted that successful DNA detection in silage was inversely related to the duration of the ensiling process. In the current study, silage sam-

Table 5. Mean values for milk production and DM intake over 12 wk of lactation, adjusted by covariance on week before the start of the study and the change in live weight and BCS during the experimental period.

\begin{tabular}{|c|c|c|c|c|c|c|}
\hline & \multicolumn{4}{|c|}{ TMR treatments } & \multirow[b]{3}{*}{$\begin{array}{l}\mathrm{SEM}^{1} \\
(40 \mathrm{df})\end{array}$} & \multirow[b]{3}{*}{$P$ value ${ }^{2}$} \\
\hline & $\mathrm{T} 1$ & & & & & \\
\hline & $\begin{array}{l}\text { Chardon } \\
\text { Liberty } \\
\text { Link }\end{array}$ & $\begin{array}{l}12 \\
\text { Near- } \\
\text { isogenic }\end{array}$ & $\frac{\mathrm{T} 3}{\text { Fabius }}$ & $\frac{\mathrm{T} 4}{\text { Antares }}$ & & \\
\hline Milk yield (kg/d) & 35.3 & 33.7 & 34.0 & 35.2 & 0.73 & 0.290 \\
\hline $\begin{array}{l}\text { Composition }(\mathrm{g} / \mathrm{kg}) \\
\text { Fat } \\
\text { Protein } \\
\text { Lactose }\end{array}$ & $\begin{array}{l}39.2 \\
34.7 \\
47.1\end{array}$ & $\begin{array}{l}39.2 \\
35.4 \\
47.1\end{array}$ & $\begin{array}{l}38.6 \\
35.6 \\
47.5\end{array}$ & $\begin{array}{l}38.3 \\
35.0 \\
47.2\end{array}$ & $\begin{array}{l}1.25 \\
0.33 \\
0.20\end{array}$ & $\begin{array}{l}0.945 \\
0.244 \\
0.517\end{array}$ \\
\hline $\begin{array}{l}\text { Constituent yield }(\mathrm{g} / \mathrm{d}) \\
\text { Fat } \\
\text { Protein } \\
\text { Lactose }\end{array}$ & $\begin{array}{l}1373 \\
1190 \\
1657\end{array}$ & $\begin{array}{l}1303 \\
1192 \\
1591\end{array}$ & $\begin{array}{l}1299 \\
1198 \\
1612\end{array}$ & $\begin{array}{l}1332 \\
1244 \\
1664\end{array}$ & $\begin{array}{l}44.5 \\
21.8 \\
35.3\end{array}$ & $\begin{array}{l}0.649 \\
0.283 \\
0.408\end{array}$ \\
\hline $\begin{array}{l}\text { Total DM intake }(\mathrm{kg} / \mathrm{d}) \\
\text { Live weight gain }(\mathrm{kg}) \\
\text { BSC }\end{array}$ & $\begin{array}{r}23.7^{\mathrm{a}} \\
25.7^{\mathrm{a}} \\
1.90\end{array}$ & $\begin{array}{r}22.4^{\mathrm{b}} \\
59.1^{\mathrm{b}} \\
1.98\end{array}$ & $\begin{array}{r}24.3^{\mathrm{a}} \\
31.1^{\mathrm{a}} \\
1.97\end{array}$ & $\begin{array}{r}24.0^{\mathrm{a}} \\
25.7^{\mathrm{a}} \\
1.89\end{array}$ & $\begin{array}{l}0.33 \\
6.21 \\
0.13\end{array}$ & $\begin{array}{l}0.002 \\
0.001 \\
0.948\end{array}$ \\
\hline
\end{tabular}

${ }^{\mathrm{a}, \mathrm{b}}$ Treatments with different letters are significant at the $5 \%$ level.

${ }^{1}$ Standard error of mean for the 4 TMR treatments.

${ }^{2}$ Probability value to assess significance of treatment differences. 
Table 6. Detection of positive (+), negative (-), and inconclusive (I) PCR results for each amplicon measured in milk from cows receiving a nonGM TMR in the pretreatment period and either a TMR containing the GM corn silage from Chardon Liberty Link (T1) or its near-isogenic nonGM (T2) corn silage at wk 1, 6, and 12 of the experimental feeding period.

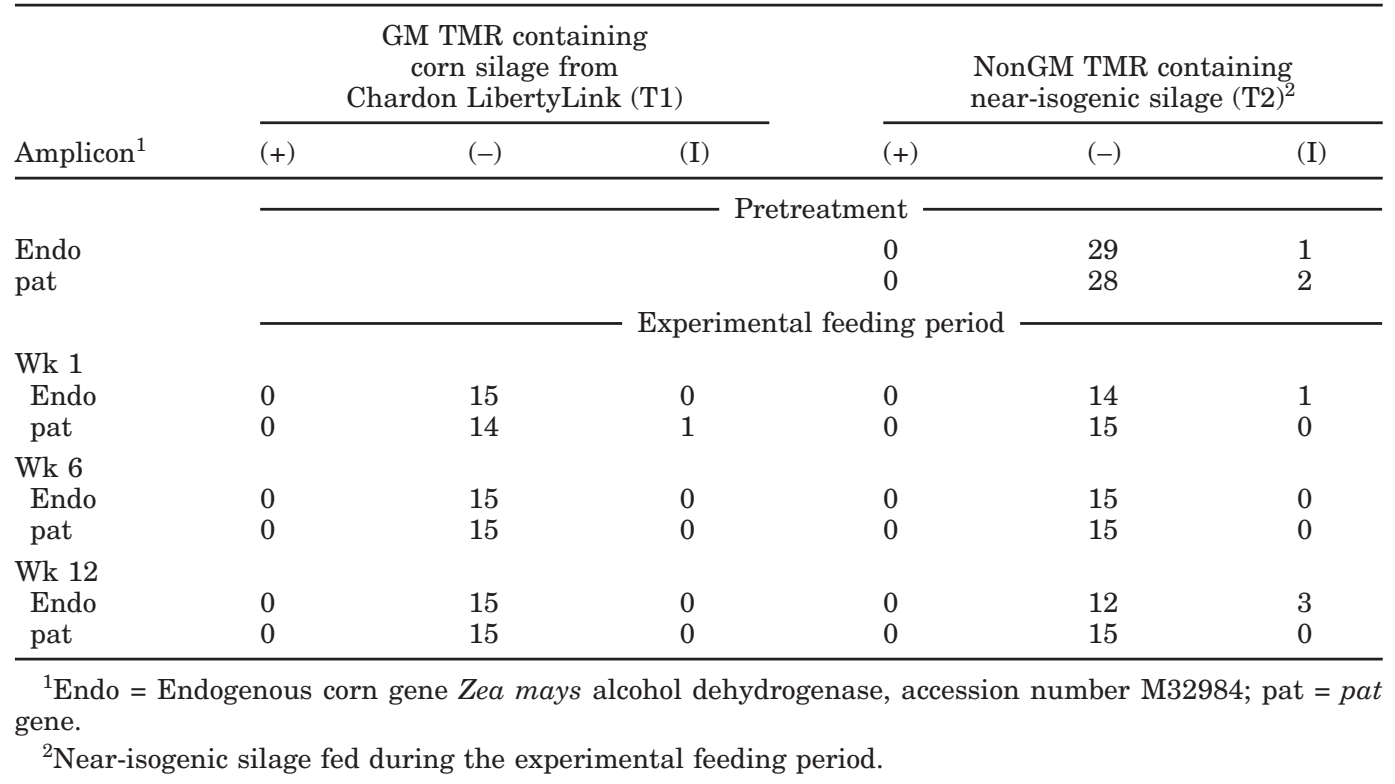

ples had been in clamps for approximately 90 to $180 \mathrm{~d}$, and the size of the amplicon used for detection of the PAT gene was relatively large, which explains the inconsistency noted in the detection of the pat amplicon in the Chardon LL silage.

Milk. Table 6 presents the number of positive, negative, and inconclusive PCR results for the pat and endogenous corn gene in the milk samples. In the pretreatment and treatment periods, none of the milk samples analyzed was positive above a detection limit of $2.5 \mathrm{ng}$ of total genomic DNA $/ \mathrm{mL}$ of milk for either tDNA (event T25) or the endogenous corn gene. As is often the case with this type of analysis, a very small number of inconclusive results were noted. These results agree with earlier studies, which reported that tDNA could not be detected in milk derived from cows offered diets containing a range of different GM feed ingredients (Einspanier et al., 2001; Phipps et al., 2002, 2003; Calsamiglia et al., 2003).

The ELISA assay results showed a degree of inconsistency indicating that the ELISA kit used was not ideally suited for the analysis of bovine milk (it had been developed primarily for plant material). However, it was possible to establish a reliable LOD of $3 \mathrm{ng}$ of PAT protein/ $\mathrm{mL}$ of milk; all but one set of milk samples tested was negative at this level. The exception was one cow offered the TMR containing the T25 construct, whose milk gave an apparent false positive test result for PAT protein in all the sampled weeks including the pretreatment week. It is suggested that this result was caused by a cross-reaction between a protein factor present in the milk and the ELISA kit used in the assay.

\section{CONCLUSIONS}

The study showed that the nutritive value, fermentation characteristics, mineral composition, and AA content of GM corn silage (event T25), and the milk production achieved when this silage was incorporated in a TMR are similar to those recorded for its nonGM nearisogenic counterpart, and the commercial varieties used in this study. The current paper confirms earlier work that showed that tDNA and the protein expressed by the inserted gene could not be detected in milk derived from dairy cows receiving diets containing GM feed ingredients.

\section{ACKNOWLEDGMENTS}

The authors thank R. J. Summerfield, R. H. Ellis, and D. E. Beever for their support in the establishment of the study, and Bayer CropScience (Cambridge, UK) for financial support.

\section{REFERENCES}

Aulrich, K., G. Pahlow, and G. Flachowsky. 2004. Influence of ensiling on DNA-degradation in isogenic and transgenic corn. Proc. Soc. Nutr. Physiol. 13:112. (Abstr.)

Calsamiglia, S., B. Hernandez, G. F. Hartnell, and R. H. Phipps. 2003. Effect of feeding corn silage produced from corn containing MON810 and GA21 genes on feed intake, milk production and 
composition in lactating dairy cows. J. Dairy Sci. 86(Suppl. 1):247. (Abstr.)

Clark, J. H., and I. R. Ipharraguerre. 2001. Livestock performance: Feeding biotech crops. J. Dairy Sci. 84(E Suppl.):E9-E18.

Doyle, J. J., and J. L. Doyle. 1987. A rapid DNA isolation procedure for small quantities of fresh leaf tissue. Phytochem. Bull. 19:11-15.

Einspanier, R., A. Klotz, J. Kraft, K. Aulrich, R. Poser, F. Schwagele, G. Jahreis, and G. Flachowsky. 2001. The fate of forage DNA in farm animals: A collaborative case study investigating cattle and chicken fed recombinant plant material. Eur. Food Res. Technol. 212:129-134.

Flachowsky, G., and K. Aulrich. 2001. Nutritional assessment of feeds from genetically modified organisms. J. Anim. Feed Sci. 10(Suppl. 1):181-194.

Givens, D. I., B. Cottyn, P. J. S. Dewey, and A. Steg. 1995. A comparison of the neutral detergent-cellulase method with other laboratory methods for predicting the digestibility in-vivo of maize silage from three European countries. Anim. Feed Sci. Technol. 54:55-64.

Grant, R. J., K. C. Fanning, D. Kleinschmit, E. P. Stannisiewski, and G. F. Hartnell. 2003. Influence of glyphosate-tolerant (event NK603) and corn rootworm protected (event MON863) corn silage and grain on feed consumption and milk production in Holstein cattle. J. Dairy Sci. 86:1707-1715.

Home Office. 1986. Animal Scientific Procedures Act of 1986. Her Majesty's Stationary Office, London, UK.

Hupfer, C., J. Mayer, H. Hotzel, K. Sachse, and K. H. Engel. 1999. The effect of ensiling on PCR-based detection of genetically modified Bt maize. Eur. Food Res. Technol. 209:301-304.

International Life Sciences Institute. 2004. Crop composition database, ver. 2. Online. http://cropcomposition.org. Accessed Jan. $27,2005$.

Ipharraguerre, I. R., R. S. Younker, J. H. Clark, E. P. Stannisiewski, and G. F. Hartnell. 2003. Performance of lactating dairy cows fed corn as whole plant silage and grain produced from a glyphosatetolerant hybrid (NK603). J. Dairy Sci. 86:1734-1741.

James, C. 2004. Global review of commercialized transgenic crops. International Service for the Acquisition of Agri-Biotech Applications, Ithaca, NY.
Maize Growers Association. 2002. Recommended First Choice Forage Maize Varieties. Maize Growers Association, Hall Farm, Berkshire, UK.

Ministry of Agriculture, Fisheries, and Food. 1993. Prediction of energy values of compound feedstuffs for farm animals. Booklet 1285. MAFF Publications, Alnwick, UK.

Mulvanny, P. 1977. A body condition scoring technique for use with British Friesians. Anim. Sci. 24:157-158.

OECD. 2002. Series on the Safety of Novel Foods and Feeds No. 5. Consensus document on compositional considerations for new varieties of maize (Zea mays): Key food and feed nutrients and anti-nutrients and secondary metabolites. Organization for Economic Co-operation and Development, Paris, France.

OECD. 2003. Series on the Safety of Novel Foods and Feeds No. 9. Considerations for the safety assessment of animal feedstuffs derived from genetically modified plants. Organization for Economic Co-operation and Development, Paris, France.

Offer, N. W., B. R. Cotterill, and C. Thomas. 1996. Relationship between silage evaluation and animal response. Pages 26-38 in Proc. 11th Int. Silage Conf. Inst. Grassl. Environ. Res., Aberystwyth, UK

Phipps, R. H., D. E. Beever, and D. J. Humphries. 2002. Detection of transgenic DNA in milk from cows receiving herbicide tolerant (CP4EPSPS) soybean meal. Livest. Prod. Sci. 73:269-273.

Phipps, R. H., E. R. Deaville, and B. C. Maddison. 2003. Detection of transgenic DNA and protein in rumen fluid, duodenal digesta, milk, blood, and feces of lactating dairy cows. J. Dairy Sci. 86:4070-4078.

Phipps, R. H., J. D. Sutton, D. E. Beever, and A. K. Jones. 2000. The influence of crop maturity on the nutritional value of maize silage for lactating dairy cows. Part 3. Food intake and milk production. Anim. Sci. 71:401-409.

Royal Society. 2003. Farm scale evaluations of spring-sown genetically modified crop. Philos. Trans. R. Soc. Lond. B, Biol. Sci. 358:1773-1913.

Zimmerman, A., J. Luthy, and U. Pauli. 1998. Quantitative and qualitative evaluation of nine different extraction methods for nucleic acids on soya bean food samples. Z. Lebensm.-Unters.-Forsch. 207:81-90. 